\title{
FIXED POINTS SET FUNCTION OF NONEXPANSIVE RANDOM MAPPING ON METRIC SPACES
}

\author{
ISMAT BEG
}

Abstract. We prove that the set of random fixed points of a nonexpansive random map on a uniformly convex complete separable metric space is nonempty. We also show that the fixed point set function of a nonexpansive random map is closed and convex valued.

Mathematics subject classification (2000): 47H40, 47H09, 47H10, 54H25, 60H25. convexity.

Key words and phrases: Metric spaces, nonexpansive random map, random fixed point, uniform

\section{REFERENCES}

[1] I. BEG, Structure of the set of fixed points of nonexpansive mappings on convex metric spaces, Annales, Univ. Mariae Curie - Sklodowska, (Sec. A) LII (2) (1) (1998), 7-14.

[2] I. BEG, Minimal displacement of random variables under Lipschitz random maps, Topological Methods in Nonlinear Analysis, 19 (2) (2002), 391-397.

[3] I. Beg, A. AZAm, F. Ali And T. Minhas, Some fixed point theorems in convex metric spaces, Rendiconti., Circolo Mathematico Di Palermo XL (1991), 307-315.

[4] I. BEG AND N. SHAHZAD, A general fixed points theorem for a class of continuous random operators, New Zealand J. Math., 26 (1997), 21-24.

[5] I. BEg AND N. SHAHZAD, Some random approximation theorems with applications, Nonlinear Analysis, 35 (1999), 609-616.

[6] I. BEG, N. ShaHZAD AND M. IQBAL, Fixed point theorems and best approximation in convex metric spaces, J. Approx. Theory and its Appl. 8 (4) (1992), 97-105.

[7] A. T. BharUCHA-ReID, Random Integral Equations, Academic Press, New York, 1972.

[8] A. T. BHARUCHA-REID, Fixed point theorems in probabilistic analysis, Bull. Amer. Math. Soc., 82 (1976), 641-657.

[9] S. ITOH, Random fixed point theorems with an application to random differential equations in Banach spaces, J. Math. Anal. Appl., 67 (1979), 261-273.

[10] L. CIRIC, On some discontinuous fixed point theorems in convex metric spaces, Czech. Math. J. 43 (188) (1993), 319-326.

[11] M. D. GuAY, K. L. Singh AND J. H. M. WhitfiELD, Fixed point theorems for nonexpansive mappings in convex metric spaces, Proceeding, Conference on Nonlinear Analysis (Edited by S. P. Singh and J. H. Barry), Marcel Dekker Inc. New York 80 (1982), 179-189.

[12] S. A. NAimpally, K. L. Singh AND J. H. M. WhitField, Fixed points in convex metric spaces, Math. Japonica 29 (4) (1984), 585-597.

[13] N. S. PAPAGEORGIOU, Random fixed point theorems for measurable multifunctions in Banach spaces, Proc. Amer. Math. Soc., 97 (1986), 507-514.

[14] N. S. PAPAgeORgIoU, On measurable multifunctions with stochastic domain, J. Austral. Math. Soc. (Ser-A), 45 (1988), 204-216.

[15] V. M. Sehgal And S. P. Singh, On random approximations and a random fixed point theorem for set valued mappings, Proc. Amer. Math. Soc., 95 (1985), 91-94.

[16] T. SHIMIZU AND W. TAKAHASHI, Fixed point theorems in certain convex metric spaces, Math Japon. 37 (1992), 855-859. 
[17] T. SHIMIZU AND W. TAKAHASHI, Fixed points of multivalued mappings in certain convex metric spaces, Topological Methods in Nonlinear Analysis, 8 (1996), 197-203.

[18] G. F. SimMOnS, Topology and Modern Analysis, McGraw-Hill Inc., 1963.

[19] W. TAKAHASHI, A convexity in metric spaces and nonexpansive mapping I, Kodai Math. Sem. Rep. 22 (1970), 142-149.

[20] K. K. TAN AND X. Z. YUAN, Some random fixed point theorems, Fixed Point Theory and Applications (Ed: K. K. Tan), World Scientific, Singapore, 1992, 334-345.

[21] K. K. TAN AND X. Z. YuAn, On deterministic and random fixed points, Proc. Amer. Math. Soc., 119 (1993), 849-856.

[22] H. K. XU, A random fixed point theorem for multivalued nonexpansive operators in uniformly convex Banach spaces, Proc. Amer. Math. Soc., 117 (1993), 1089-1092.

[23] H. K. XU AND I. BEG, Measurability of fixed point sets of multivalued random operators, J. Math. Anal. Appl., 225 (1998), 62-72. 